\title{
Penerapan Metode Discovery Learning Untuk Meningkatkan Prestasi Belajar Fisika Materi Listrik Arus Searah Pada Siswa Kelas XII MIPA 3 Tahun Pelajaran 2019/2020
}

\author{
Nelda Roza \\ SMA Negeri 2 Siak Hulu, Jl. Kubang Raya, No 62, Kubang Jaya, Kec. Siak Hulu, Kabupaten Kampar, Riau, Indonesia \\ neldaroza11@gmail.com
}

\begin{abstract}
There were problems related to student achievement in class XII MIPA 3 so it is necessary to find a solution through a study. The purpose of this research was to improve the physics learning achievement of direct current electric material in class XII MIPA 3 academic year 2019/2020 through the application of the discovery learning method. The research was conducted in Class XII of SMAN 2 Siak Hulu. Implementation time is from July to September 2019. Based on the results of learning activities Direct Current Electrical Material physics that have been carried out for three cycles, and based on all the discussions and analyzes that have been carried out, it can deactivate the Physics learning of Direct Current Electricity material by active learning. positive impact in increasing student achievement overcoming the increase in student learning completeness in each cycle, namely cycle I (60\%), cycle II (73\%), cycle III (90\%). The application of the active learning method of the Discovery Learning method in Physics subjects has a positive effect, namely it can increase student motivation as indicated by the average student's answer which states that students are interested and interested in learning models so that they become motivated to learn. The application of the active learning method of the Discovery Learning method in Physics subjects can improve mastery of Physics subjects with the subject of Direct Current Electricity and understanding the meaning contained therein.
\end{abstract}

Keywords: Discovery Learning Method, Learning Achievement, Direct Electric Current Material

\begin{abstract}
Abstrak
Adanya permasalahan terkait prestasi belajar siswa di kelas XII MIPA 3 maka perlu dicarikan solusi melalui suatu penelitian. Adapun tujuan penelitian ini adalah meningkatkan prestasi belajar fisika materi listrik arus searah pada siswa kelas XII MIPA 3 Tahun pelajaran 2019/2020 melalui penerapan metode discovery learning. Penelitian ini dilakukan di Kelas XII SMAN 2 Siak hulu. Waktu pelaksanaan pada bulan Juli sampai September 2019. Berdasarkan hasil kegiatan pembelajaran Fisika materi Listrik Arus Searah yang telah dilakukan selama tiga siklus, dan berdasarkan seluruh pembahasan serta analisis yang telah dilakukan dapat disimpulkan pembelajaran Fisika materi Listrik Arus Searah dengan cara belajar aktif Metode Discovery Learning memiliki dampak positif dalam meningkatkan prestasi belajar siswa yang ditandai dengan peningkatan ketuntasan belajar siswa dalam setiap siklus, yaitu siklus I (60\%), siklus II (73\%), siklus III (90\%). Penerapan cara belajar aktif metode Discovery Learning pada mata pelajaran Fisika ini mempunyai pengaruh positif, yaitu dapat meningkatkan motivasi belajar siswa yang ditunjukan dengan rata-rata jawaban siswa yang menyatakan bahwa siswa tertarik dan berminat dengan model belajar aktif sehingga mereka menjadi termotivasi untuk belajar. Penerapan cara belajar aktif metode Discovery Learning pada mata pelajaran Fisika ini bisa meningkatkan penguasaan mata pelajaran Fisika materi Listrik Arus Searah serta pemahaman makna yang terkandung di dalamnya.
\end{abstract}

Kata kunci: Metode Discovery Learning, Prestasi Belajar, Materi Arus Listrik Searah

Copyright (c) 2020 Nelda Roza

$\triangle$ Corresponding author: neldaroza11@gmail.com

Email Address: neldaroza11@gmail.com

Received 23 November 2020, Accepted 30 November 2020, Published 01 Desember 2020

\section{PENDAHULUAN}

Dunia pendidikan kita saat ini tengah mengalami krisis yang cukup serius. Krisis ini tidak saja disebabkan karena adanya masalah anggaran pemerintah untuk membiayai kebutuhan vital dunia pendidikan kita, lemahnya tenaga ahli, juga dapat mempengaruhi hasil prestasi belajar siswa. 
Permasalahan prestasi belajar yang menurun banyak ditemukan karena kurangnya motivasi belajar siswa serta lemahnya tenaga ahli/profesional guru yang menjadikan pembelajarannya efektif.

Guru yang tidak menghiraukan cara mengajarnya menjadikan proses pembelajaran guru kepada murid menjadi kurang mengena, karena rendahnya penguasaan konsep sehingga berpengaruh pada buruknya sikap belajar siswa juga. Hal ini disebabkan karena guru (tenaga pengajar) menggunakan pembelajaran yang masih konvensional. Pembelajaran konvensional ini masih mengedepankan metode ceramah, tanpa memperhatikan aktivitas belajar yang berpusat dari siswanya (student centered). Pembelajaran konvensional yang berlangsung cenderung berjalan satu arah dari guru ke siswa (teacher centered), menyebabkan pembelajaran terkesan hanya mentransfer pengetahuan dari guru ke siswa saja. Padahal pembelajaran Sains yang berpusat dari guru ini berjalan kurang efektif dalam mengembangkan ranah kognitif (penguasaan konsep), ranah afektif (sikap belajar), dan psikomotor siswa, hasilnya secara langsung mempengaruhi rendahnya motivasi belajar siswa sehingga juga berpengaruh pada prestasi belajar siswa. Karena sains dapat diartikan ilmu yang mempelajari sebab dan akibat dari kejadian yang terjadi di alam ini.

Pembelajaran konvensional yang menghasilkan penguasaan konsep dan sikap belajar siswa yang rendah itu, perlu diperbaiki dengan cara menerapkan model, pendekatan, dan strategi pembelajaran. Guru selain bertugas sebagai fasilitator, transfer knowledge, dan transfer of value dia harus menjadi teladan yang baik, berkepribadian yang patut jadi tauladan dan disenangi dalam pergaulan. Karena prestasi belajar anak didik juga akan berpengaruh dengan sejalannya perubahan sikap karena membeci kepribadian guru, jadi disini kepribadian guru juga sangat berpengaruh pada prestasi siswa. Menyikapi hal ini salah satu alternatif usaha guru dalam meningkatkan motivasi serta prestasi belajar adalah penggunaan pendekatan discoveri. Guru atau peneliti memilih menggunakan pendekatan discoveri agar proses belajar mengajar pada khususnya, dan proses pendidikan pada umumnya dapat berlangsung secara efektif. Hal ini disebabkan antara lain, materi pendidikan yang akan disampaikan itu main beragam dan luas mengingat perkembangan ilmu dan tekhnologi yang makin pesat, akan tetapi keadaan sekolahan, kondisi siswa dan kurangnya guru ahli (guru yang profesional) dalam memanajemen pembelajaran yang mengakibatkan motivasi dan prestasi belajar menurun perlu dibenahi.

Berdasarkan permasalahan tersebut maka strategi atau teknik, metode dan pendekatan, yang sesuai merupakan beberapa hal yang implikasinya bersama-sama dapat meningkatkan keefektifan pembelajaran untuk meningkatkan pemahaman konsep teori, motivasi, keaktifan, dan prestasi belajar. Hal ini diyakini karena melalui pendekatan discoveri dapat menjadikan belajar siswa penuh makna, belajar bukan hanya diterapkan dalam konsep akan tetapi siswa mengalami penelitan, belajar mencari sebuah penemuan dengan praktek yang akhirnya mendapat jawaban. Yang pada akhirnya jawaban mereka tersebut bisa dipakai dalam menerapkan ilmunya di kehidupan sehari-hari.

Berdasarkan latar belakang masalah tersebut, maka peneliti merasa terdorong untuk melihat pengaruh pembelajaran terstruktur dan pemberian balikan terhadap prestasi belajar siswa dengan 
Penerapan Metode Discovery Learning untuk Meningkatkan Prestasi Belajar Fisika Materi Listrik Arus Searah Pada Siswa Kelas XII MIPA 3 Tahun Pelajaran 2019/2020, Nelda Roza

mengambil judul “ Penerapan Metode Discovery Learning Guna Meningkatkan Prestasi Belajar Fisika Materi Listrik Arus Searah Pada Siswa Kelas XII MIPA 3 Tahun Pelajaran 2019/2020”

\section{METODE}

\section{Design penelitian}

Dalam kegiatan penelitian kali ini peneliti bekerja sendirian tanpa kolaborasi dengan orang lain. Kehadiran peneliti dalam kegiatan belajar mengajar dilakukan seperti biasa seperti tidak ada penelitian. Jadi siswa dibiarkan melakukan semua kegiatan seperti biasa. Penelitian ini menggunakan Penelitian Tindakan Kelas (PTK). Menurut Tim Pelatih Proyek PGSM, PTK adalah suatu bentuk kajian yang bersifat reflektif oleh pelaku tindakan yang dilakukan untuk meningkatkan kemantapan rasional dari tindakan mereka dalam melaksanakan tugas, memperdalam pemahaman terhadap tindakan-tindakan yang dilakukan itu, serta memperbaiki kondisi dimana praktek pembelajaran tersebut dilakukan (dalam Mukhlis, 2003: 3). Sedangkan menurut Muhlis (2003: 5) PTK adalah suatu bentuk kajian yang bersifat sistematis reflektif oleh pelaku tindakan untuk memperbaiki kondisi pembelajaran yang dilakukan. Adapun tujuan utama dari PTK adalah untuk memperbaiki/meningkatkan praktek pembelajaran secara berkesinambungan, sedangkan tujuan penyertaannya adalah menumbuhkan budaya meneliti di kalangan guru (Mukhlis, 2003: 5).

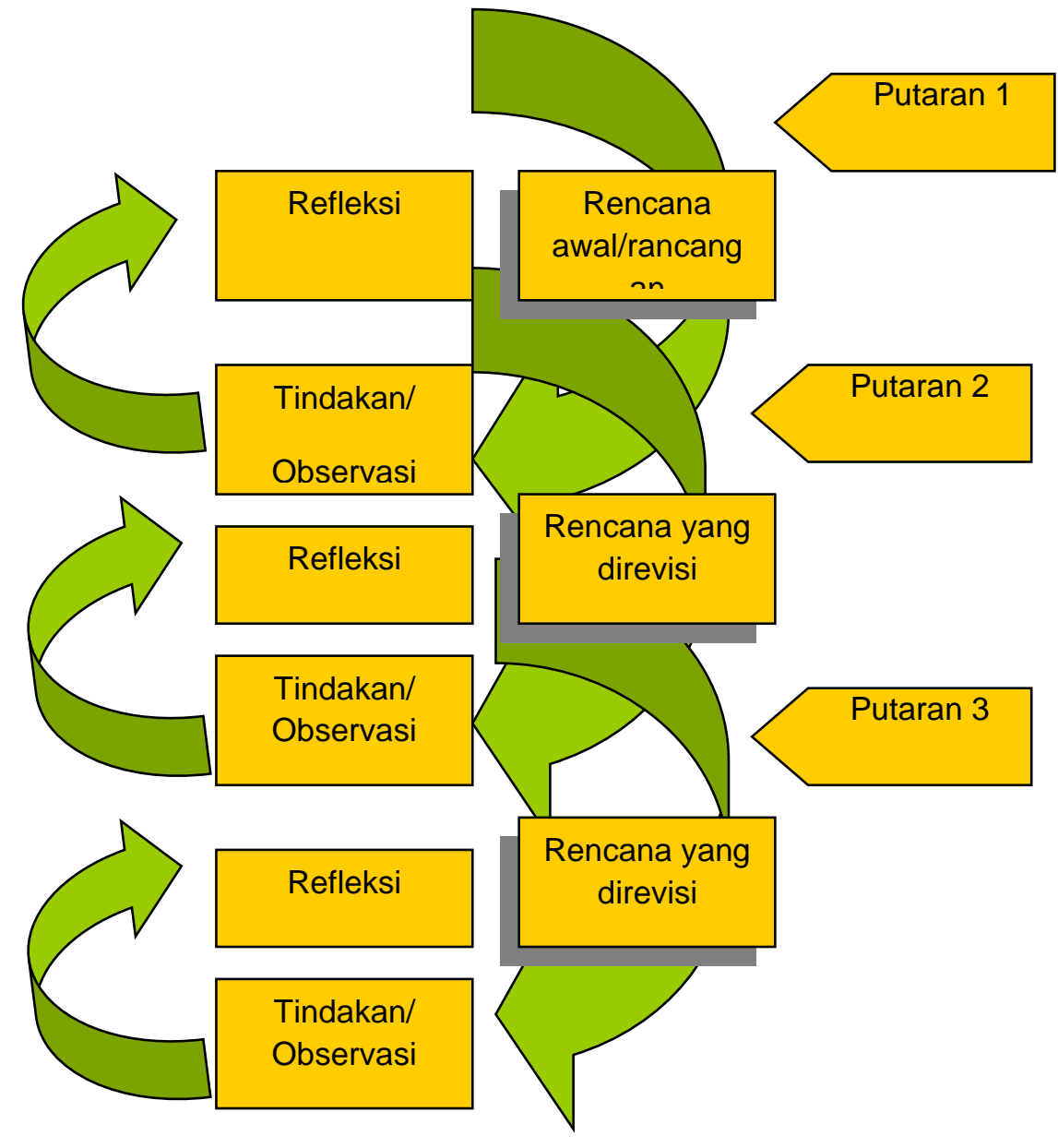

Gambar 1. Alur PTK 


\section{Tempat, Waktu, dan Subjek Penelitian}

Tempat penelitian adalah tempat yang digunakan dalam melakukan penelitian untuk memperoleh data yang diinginkan. Penelitian ini bertempat di Kelas XII. Waktu penelitian adalah waktu berlangsungnya penelitian atau saat penelitian ini dilangsungkan. Penelitian ini dilaksanakan pada bulan Juli sampai September 2019 semester ganjil Tahun Pelajaran 2019/2020. Subjek penelitian adalah siswa-siswi Kelas XII MIPA 3 Tahun Pelajaran 2019/2020 pada mata pelajaran Fisika materi Listrik Arus Searah.

Sesuai dengan jenis penelitian yang dipilih, yaitu penelitian tindakan, maka penelitian ini menggunakan model penelitian tindakan dari Kemmis dan Taggart (dalam Sugiarti, 1997: 6), yaitu berbentuk spiral dari sklus yang satu ke siklus yang berikutnya. Setiap siklus meliputi planning (rencana), action (tindakan), observation (pengamatan), dan reflection (refleksi). Langkah pada siklus berikutnya adalah perencanaan yang sudah direvisi, tindakan, pengamatan, dan refleksi. Sebelum masuk pada siklus 1 dilakukan tindakan pendahuluan yang berupa identifikasi permasalahan.

\section{Instrumen Penelitian}

Tes ini disusun berdasarkan tujuan pembelajaran yang akan dicapai, digunakan untuk mengukur kemampuan penguasaan dan pemahaman materi. Tes formatif ini diberikan setiap akhir putaran. Bentuk soal yang diberikan adalah pilihan ganda (objektif). Sebelumnya soal-soal ini berjumlah 45 soal yang telah diujicoba, kemudian penulis mengadakan analisis butir soal tes yang telah diuji validitas dan reliabilitas pada tiap soal. Analisis ini digunakan untuk memilih soal yang baik dan memenuhi syarat digunakan untuk mengambil data. Langkah-langkah analisis butir soal adalah sebagai berikut:

\section{Validitas Tes}

Validitas butir soal atau validitas item digunakan untuk mengetahui tingkat kevalidan masingmasing butir soal. Sehingga dapat ditentukan butir soal yang gagal dan yang diterima. Tingkat kevalidan ini dapat dihitung dengan korelasi Product Moment:

$$
\begin{aligned}
& r_{x y}=\frac{N \sum X Y-\left(\sum X\right)\left(\sum Y\right)}{\sqrt{\left\{N \sum X^{2}-\left(\sum X\right)^{2}\right)\left(N \sum Y^{2}-\left(\sum Y\right)^{2}\right\}}} \text { (Suharsimi Arikunto, 2001: 72) } \\
& \text { Dengan: } \quad \mathrm{r}_{\mathrm{xy}} \quad: \text { koefisien korelasi product moment } \\
& \mathrm{N} \quad: \text { jumlah peserta tes } \\
& \Sigma \mathrm{Y} \quad: \text { jumlah skor total } \\
& \Sigma \mathrm{X} \quad: \text { jumlah skor butir soal } \\
& \Sigma \mathrm{X}^{2} \quad: \text { jumlah kuadrat skor butir soal } \\
& \Sigma \mathrm{XY} \quad: \text { jumlah hasil kali skor butir soal }
\end{aligned}
$$

\section{Reliabilitas Tes}

Reliabilitas butir soal dalam penelitian ini menggunakan rumus belah dua sebagai berikut: 


$$
\begin{array}{ll}
r_{11}=\frac{2 r_{1 / 21 / 2}}{\left(1+r_{1 / 21 / 2}\right)} & \text { Suharsimi Arikunto, 20001: 93) } \\
\text { Dengan: } \quad r_{11} \quad: \text { koefisien reliabilatas yang sudah disesuaikan } \\
\quad r_{1 / 21 / 2}: \text { korelasi antara skor-skor setiap belahan tes }
\end{array}
$$

Kriteria reliabilitas tes jika harga $r_{11}$ dari perhitungan lebih besar dari harga $r$ pada tabel product moment maka tes tersebut reliable.

\section{Taraf Kesukaran}

Bilangan yang menunjukkan sukar dan mudahnya suatu soal adalah indeks kesukaran. Rumus yang digunakan untuk menentukan taraf kesukaran adalah:

$$
\begin{array}{rll}
P=\frac{B}{J_{S}} & \text { (Suharsimi Arikunto, 2001: 208) } \\
\text { Dengan: } & \mathrm{P} & \text { : Indeks kesukaran } \\
& \mathrm{B} & \text { : banyak siswa yang menjawab soal dengan benar } \\
& \text { Js } & \text { : Jumlah seluruh siswa peserta tes }
\end{array}
$$

Kriteria untuk menentukan indeks kesukaran soal adalah sebagai berikut:

- $\quad$ Soal dengan $P=0,000$ sampai 0,300 adalah sukar

- Soal dengan $P=0,301$ sampai 0,700 adalah sedang

- Soal dengan $\mathrm{P}=0,701$ sampai 1,000 adalah mudah

\section{Daya Pembeda}

Daya pembeda soal adalah kemampuan suatu soal untuk membedakan antara siswa yang berkemampuan tinggi dengan siswa yang berkemampuan rendah. Angka yang menunjukkan besarnya daya pembeda disebut indeks diskriminasi. Rumus yang digunakan untuk menghitung indeks diskriminasi adalah sebagai berikut:

$$
D=\frac{B_{A}}{J_{A}}-\frac{B_{B}}{J_{B}}=P_{A}-P_{B} \quad \text { (Suharsimi Arikunto, 2001: 211) }
$$

\section{Dimana:}

D : Indeks diskriminasi

$\mathrm{B}_{\mathrm{A}}$ : Banyak peserta kelompok atas yang menjawab dengan benar

$\mathrm{B}_{\mathrm{B}}$ : Banyak peserta kelompok bawah yang menjawab dengan benar

$\mathrm{J}_{\mathrm{A}}$ : Jumlah peserta kelompok atas

$\mathrm{J}_{\mathrm{B}}$ : Jumlah peserta kelompok bawah

$$
\begin{aligned}
& P_{A}=\frac{B_{A}}{J_{A}}=\text { proporsi peserta kelompok atas yang menjawab benar. } \\
& P_{B}=\frac{B_{B}}{J_{B}}=\text { proporsi peserta kelompok bawah yang menjawab benar }
\end{aligned}
$$

Kriteria yang digunakan untuk menentukan daya pembeda butir soal sebagai berikut: 
- Soal dengan $\mathrm{D}=0,000$ sampai 0,200 adalah kurang

- Soal dengan $\mathrm{D}=0,201$ sampai 0,400 adalah cukup

- Soal dengan $\mathrm{D}=0,401$ sampai 0,700 adalah baik

- Soal dengan $\mathrm{D}=0,701$ sampai 1,000 adalah sangat baik

\section{HASIL DAN DISKUSI}

\section{Analisis Data Penelitian Persiklus}

Sebelum melaksanakan pengambilan data melalui instrument penelitian berupa tes dan mendapatkan tes yang baik, maka data tes tersebut diuji dan dianalisis. Uji coba dilakukan pada siswa di luar sasaran penelitian. Analisis tes yang dilakukan meliputi:

\section{Siklus 1}

\section{Tahap Perencanaan}

Pada tahap ini peneliti mempersiapkan perangkat pembelajaran yang terdiri dari Rencana Pelaksanaan Pembelajaran I, soal tes formatif I dan alat-alat pengajaran yang mendukung.

\section{Tahap Kegiatan dan Pelaksanaan}

Pelaksanaan kegiatan belajar mengajar untuk siklus I dilaksanakan pada tanggal 5 September 2019 di Kelas XII dengan jumlah 30 siswa. Dalam hal ini peneliti bertindak sebagai guru. Adapun proses belajar mengajar mengacu pada Rencana Pelaksanaan Pembelajaran yang telah dipersiapkan. Pengamatan (observasi) dilaksanakan bersamaan dengan pelaksaaan belajar mengajar.

Pada akhir proses belajar mengajar siswa diberi tes formatif I dengan tujuan untuk mengetahui tingkat keberhasilan siswa dalam proses belajar mengajar yang telah dilakukan. Adapun data hasil penelitian pada siklus I adalah sebagai berikut:

Tabel 1. Pengelolaan Pembelajaran Pada Siklus I

\begin{tabular}{|c|c|c|c|c|}
\hline \multirow{2}{*}{ No } & \multirow{2}{*}{ Aspek yang diamati } & \multicolumn{2}{|c|}{ Penilaian } & \multirow{2}{*}{$\begin{array}{c}\text { Rata- } \\
\text { rata }\end{array}$} \\
\hline & & $\mathrm{P} 1$ & $\mathrm{P} 2$ & \\
\hline \multicolumn{5}{|c|}{ Pengamatan KBM } \\
\hline \multirow{13}{*}{ I } & A. Pendahuluan & 2 & 2 & 2 \\
\hline & 1. Memotivasi siswa & 2 & 2 & 2 \\
\hline & 2. Menyampaikan tujuan pembelajaran & & & \\
\hline & 3. Menghubungkan dengan pelajaran sebelumnya & & & \\
\hline & 4. Mengatur siswa dalam kelompok-kelompok belajar & & & \\
\hline & B. Kegiatan inti & & & \\
\hline & $\begin{array}{l}\text { 1. Mempresentasikan langkah-langkah metode } \\
\text { pembelajaran kooperatif }\end{array}$ & 3 & 3 & 3 \\
\hline & 2. Membimbing siswa melakukan kegiatan & 3 & 3 & 3 \\
\hline & 3. Melatih keterampilan kooperatif & 3 & 3 & 3 \\
\hline & 4. Mengawasi setiap kelompok secara bergiliran & & & \\
\hline & $\begin{array}{l}\text { 5. Memberikan bantuan kepada kelompok yang } \\
\text { mengalami kesulitan }\end{array}$ & 3 & 3 & 3 \\
\hline & C. Penutup & & & \\
\hline & 1. Membimbing siswa membuat rangkuman & 3 & 3 & 3 \\
\hline
\end{tabular}


Penerapan Metode Discovery Learning untuk Meningkatkan Prestasi Belajar Fisika Materi Listrik Arus Searah Pada Siswa Kelas XII MIPA 3 Tahun Pelajaran 2019/2020, Nelda Roza

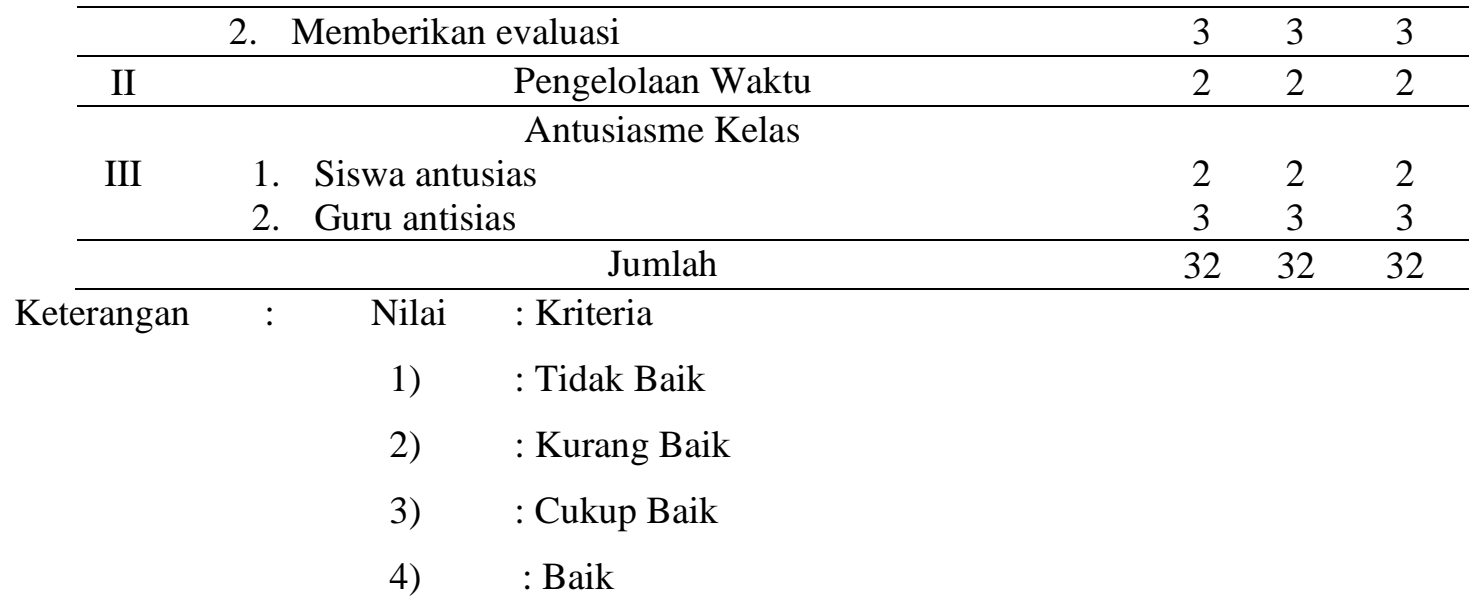

Berdasarkan tabel 1 aspek-aspek yang mendapatkan kriteria kurang baik adalah memotivasi siswa, menyampaikan tujuan pembelajran, pengelolaan waktu, dan siswa antusias. Keempat aspek yang mendapat nilai kurang baik di atas, merupakan suatu kelemahan yang terjadi pada siklus I dan akan dijadikan bahan kajian untuk refleksi dan revisi yang akan dilakukan pada siklus II.

Tabel 2. Rekapitulasi Hasil Tes Formatif Siswa Pada Siklus I

\begin{tabular}{llc}
\hline No & \multicolumn{1}{c}{ Uraian } & Hasil Siklus I \\
\hline 1 & Nilai rata-rata tes formatif & 71 \\
2 & Jumlah siswa yang tuntas belajar & 20 \\
3 & Persentase ketuntasan belajar & $60 \%$ \\
\hline
\end{tabular}

Berdasarkan tabel 2 dapat dijelaskan bahwa dengan menerapkan pembelajaran model Discovery Learning diperoleh nilai rata-rata prestasi belajar siswa adalah 71 dan ketuntasan belajar mencapai $60 \%$ atau ada 18 siswa dari 30 siswa sudah tuntas belajar. Hasil tersebut menunjukkan bahwa pada siklus pertama secara klasikal siswa belum tuntas belajar, karena siswa yang memperoleh nilai $\geq 65$ hanya sebesar $60 \%$ lebih kecil dari persentase ketuntasan yang dikehendaki yaitu sebesar $85 \%$. Hal ini disebabkan karena siswa masih merasa baru dan belum mengerti apa yang dimaksudkan dan digunakan guru dengan menerapkan pembelajaran model Discovery Learning .

\section{Siklus II}

\section{Tahap perencanaan}

Pada tahap inipeneliti mempersiapkan perangkat pembelajaran yang terdiri dari rencana pelaksanaan pembelajaran II, soal tes formatif II dan alat-alat pengajaran yang mendukung.

\section{Tahap Kegiatan dan Pelaksanaan}

Pelaksanaan kegiatan belajar mengajar untuk siklus II dilaksanakan pada tanggal 15 Juli 2019di Kelas XII dengan jumlah siswa 30 siswa. Dalam hal ini peneliti bertindak sebagai guru. Adapun proses belajar mengajar mengacu pada rencana pelaksanaan pembelajaran dengan memperhatikan revisi pada siklus I, sehingga kesalahan atau kekurangan pada siklus I tidak terulang lagi pada siklus II. 
Pengamatan (observasi) dilaksanakan bersamaan dengan pelaksanaan belajar mengajar. Pada akhir proses belajar mengajar siswa diberi tes formatif II dengan tujuan untuk mengetahui tingkat keberhasilan siswa dalam proses belajar mengajar yang telah dilakukan. Instrumen yang digunakan adalah tes formatif II. Adapun data hasil penelitian pada siklus II adalah sebagai berikut:

Tabel 3. Pengelolaan Pembelajaran Pada Siklus II

\begin{tabular}{|c|c|c|c|c|}
\hline \multirow{2}{*}{ No } & \multirow{2}{*}{ Aspek yang diamati } & \multicolumn{2}{|c|}{ Penilaian } & \multirow{2}{*}{$\begin{array}{l}\text { Rata- } \\
\text { rata }\end{array}$} \\
\hline & & $\mathrm{P} 1$ & $\mathrm{P} 2$ & \\
\hline & $\begin{array}{ll} & \text { Pengamatan KBM } \\
\text { D. Pendahuluan } & \\
\text { 1. Memotivasi siswa } \\
\text { 2. Menyampaikan tujuan pembelajaran } \\
\text { 3. Menghubungkan dengan pelajaran sebelumnya } \\
\text { 4. Mengatur siswa dalam kelompok-kelompok belajar }\end{array}$ & $\begin{array}{l}3 \\
3\end{array}$ & $\begin{array}{l}3 \\
4\end{array}$ & $\begin{array}{c}3 \\
3,5\end{array}$ \\
\hline & E. Kegiatan inti & 3 & 4 & 3,5 \\
\hline I & $\begin{array}{l}\text { 1. Mempresentasikan langkah-langkah metode pembelajaran kooperatif } \\
\text { 2. Membimbing siswa melakukan kegiatan } \\
\text { 2. Melatih keterampilan kooperatif }\end{array}$ & $\begin{array}{l}4 \\
4\end{array}$ & $\begin{array}{l}4 \\
4\end{array}$ & $\begin{array}{l}4 \\
4\end{array}$ \\
\hline & $\begin{array}{l}\text { 3. Mengawasi setiap kelompok secara bergiliran } \\
\text { 4. Memberikan bantuan kepada kelompok yang mengalami kesulitan }\end{array}$ & 4 & $\begin{array}{l}4 \\
3\end{array}$ & 4 \\
\hline
\end{tabular}

A. Penutup

1. Membimbing siswa membuat rangkuman $\quad \begin{array}{lll}3 & 4 & 3,5\end{array}$

2. Memberikan evaluasi

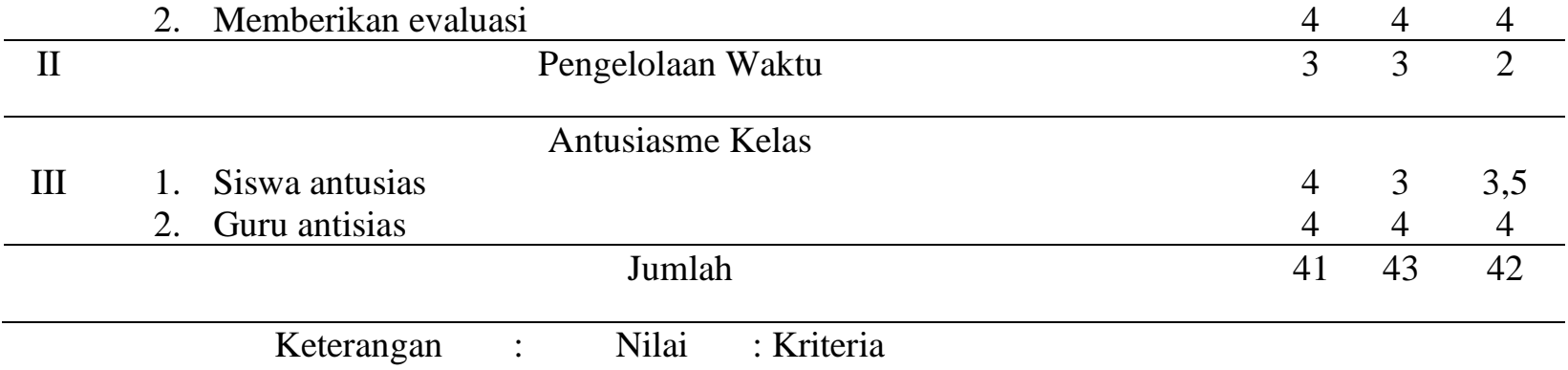
1) : Tidak Baik
2) : Kurang Baik
3) : Cukup Baik
4) : Baik

Dari tabel di atas, tanpak aspek-aspek yang diamati pada kegiatan belajar mengajar (siklus II) yang dilaksanakn oleh guru dengan menerapkan metode pembelajarn kooperatif model Discovery Learning mendapatkan penilaian yang cukup baik dari pengamat. Maksudnya dari seluruh penilaian tidak terdapat nilai kurang. Namun demikian penilaian tesebut belum merupakan hasil yang optimal, untuk itu ada beberapa aspek yang perlu mendapatkan perhatian untuk penyempurnaan penerapan pembelajaran selanjutnya. Aspek-aspek tersebut adalah memotivasi siswa, membimbing siswa merumuskan kesimpulan/ menemukan konsep, dan pengelolaan waktu. 
Penerapan Metode Discovery Learning untuk Meningkatkan Prestasi Belajar Fisika Materi Listrik Arus Searah Pada Siswa Kelas XII MIPA 3 Tahun Pelajaran 2019/2020, Nelda Roza

Dengan penyempurnaan aspek-aspek I atas alam penerapan metode pembelajarn kooperatif model Discovery Learning, diharapkan siswa dapat menyimpulkan apa yang telah mereka pelajari dan mengemukakan pendapatnya sehingga mereka akan lebih memahami tentang apa ynag telah mereka lakukan.

Tabel 4. Rekapitulasi Hasil Tes Formatif Siswa Pada Siklus II

\begin{tabular}{lll}
\hline No & Uraian & Hasil Siklus II \\
\hline 1 & Nilai rata-rata tes formatif & 74 \\
2 & Jumlah siswa yang tuntas belajar & 22 \\
3 & Persentase ketuntasan belajar & $73 \%$ \\
\hline
\end{tabular}

Dari tabel di atas diperoleh nilai rata-rata prestasi belajar siswa adalah 74 dan ketuntasan belajar mencapai $73 \%$ atau ada 22 siswa dari 30 siswa sudah tuntas belajar. Hasil ini menunjukkan bahwa pada siklus II ini ketuntasan belajar secara klasikal telah mengalami peningkatan sedikit lebih baik dari siklus I. Adanya peningkatan hasil belajar siswa ini karena setelah guru menginformasikan bahwa setiap akhir pelajaran akan selalu diadakan tes sehingga pada pertemuan berikutnya siswa lebih termotivasi untuk belajar. Selain itu siswa juga sudah mulai mengerti apa yang dimaksudkan dan diinginkan guru dengan menerapkan pembelajaran model Discovery Learning.

\section{Siklus III}

\section{Tahap Perencanaan}

Pada tahap ini peneliti mempersiapkan perangkat pembelajaran yang terdiri dari Rencana Pelaksanaan Pembelajaran III, soal tes formatif III dan alat-alat pengajaran yang mendukung.

\section{Tahap Kegiatan dan Pengamatan}

Pelaksanaan kegiatan belajar mengajar untuk siklus III dilaksanakan pada tanggal 28 Juli 2019 di Kelas XII dengan jumlah siswa 30 siswa. Dalam hal ini peneliti bertindak sebagai guru. Adapun proses belajar mengajar mengacu pada Rencana Pelaksanaan Pembelajaran dengan memperhatikan revisi pada siklus II, sehingga kesalahan atau kekurangan pada siklus II tidak terulang laig pada siklus III. Pengamatan (observasi) dilaksanakan bersamaan dengan pelaksanaan belajar mengajar.

Pada akhir proses belajar mengajar siswa diberi tes formatif III dengan tujuan untuk mengetahui tingkat keberhasilan siswa dalam proses belajar mengajar yang telah dilakukan. Instrumen yang digunakan adalah tes formatif III. Adapun data hasil penelitian pada siklus III adalah sebagai berikut: 
Tabel 5. Pengelolaan Pembelajaran Pada Siklus III

\begin{tabular}{|c|c|c|c|c|c|c|}
\hline \multirow{2}{*}{ No } & & \multirow{2}{*}{\multicolumn{2}{|c|}{ Aspek yang diamati }} & \multicolumn{2}{|c|}{ Penilaian } & \multirow{2}{*}{$\begin{array}{r}\text { Rata- } \\
\text { rata }\end{array}$} \\
\hline & & & & P1 & $\mathrm{P} 2$ & \\
\hline \multirow[t]{16}{*}{ I } & \multicolumn{3}{|l|}{ Pengamatan KBM } & 3 & 3 & 3 \\
\hline & \multicolumn{3}{|l|}{ A. Pendahuluan } & 4 & 4 & 4 \\
\hline & \multicolumn{3}{|l|}{ 1. Memotivasi siswa } & & & \\
\hline & \multirow{2}{*}{\multicolumn{3}{|c|}{ 2. Menyampaikan tujuan pembelajaran }} & & & \\
\hline & & & & & & \\
\hline & \multicolumn{3}{|c|}{ 4. Mengatur siswa dalam kelompok-kelompok belajar } & & & \\
\hline & \multicolumn{3}{|l|}{ B. Kegiatan inti } & & & \\
\hline & \multirow{2}{*}{\multicolumn{3}{|c|}{$\begin{array}{l}\text { 1. Mempresentasikan langkah-langkah metode pembelajaran kooperatif } \\
\text { 2. Membimbing siswa melakukan kegiatan }\end{array}$}} & 4 & 4 & 4 \\
\hline & & & & & & \\
\hline & \multicolumn{3}{|c|}{ 3. Melatih keterampilan kooperatif } & 4 & 4 & 4 \\
\hline & \multicolumn{3}{|c|}{ 4. Mengawasi setiap kelompok secara bergiliran } & 4 & 4 & 4 \\
\hline & \multirow{2}{*}{\multicolumn{3}{|c|}{ 5. Memberikan bantuan kepada kelompok yang mengalami kesulitan }} & 4 & 3 & 3,5 \\
\hline & & & & 3 & 3 & 3 \\
\hline & \multicolumn{6}{|l|}{ C. Penutup } \\
\hline & 1. & \multicolumn{2}{|c|}{ Membimbing siswa membuat rangkuman } & 4 & 4 & 4 \\
\hline & 2. & \multicolumn{2}{|c|}{ Memberikan evaluasi } & 4 & 4 & 4 \\
\hline II & Pengelolaan Waktu & & & 3 & 3 & 3 \\
\hline \multirow[t]{9}{*}{ III } & \multicolumn{3}{|l|}{ Antusiasme Kelas } & & & \\
\hline & 1. & & Siswa antusia & 4 & 4 & 4 \\
\hline & 2. & & Guru antisias & 4 & 4 & 4 \\
\hline & \multirow{6}{*}{ Keterangan } & & & 45 & 44 & 44,5 \\
\hline & & Nilai & : Kriteria & & & \\
\hline & & 1 & : Tidak Baik & & & \\
\hline & & 2. & : Kurang Baik & & & \\
\hline & & 3. & : Cukup Baik & & & \\
\hline & & 4. & : Baik & & & \\
\hline
\end{tabular}

Tabel 6. Hasil Rekapitulasi Tes Formatif Siswa Pada Siklus III

\begin{tabular}{lll}
\hline No & Uraian & Hasil Siklus III \\
\hline 1 & Nilai rata-rata tes formatif & 79 \\
2 & Jumlah siswa yang tuntas belajar & 27 \\
3 & Persentase ketuntasan belajar & $90 \%$ \\
\hline
\end{tabular}

Berdasarkan tabel di atas diperoleh nilai rata-rata tes formatif sebesar 79 dan dari 30 siswa telah tuntas sebanyak 27 siswa dan 3 siswa belum mencapai ketuntasan belajar. Maka secara klasikal ketuntasan belajar yang telah tercapai sebesar 90\% (termasuk kategori tuntas). Hasil pada siklus III ini mengalami peningkatan lebih baik dari siklus II. Adanya peningkatan hasil belajar pada siklus III ini dipengaruhi oleh adanya peningkatan kemampuan guru dalam menerapkan pembelajaran model Discovery Learning sehingga siswa menjadi lebih terbiasa dengan pembelajaran seperti ini sehingga siswa lebih mudah dalam memahami materi yang telah diberikan. 
Penerapan Metode Discovery Learning untuk Meningkatkan Prestasi Belajar Fisika Materi Listrik Arus Searah Pada Siswa Kelas XII MIPA 3 Tahun Pelajaran 2019/2020, Nelda Roza

\section{Refleksi}

Pada tahap ini akah dikaji apa yang telah terlaksana dengan baik maupun yang masih kurang baik dalam proses belajar mengajar dengan penerapan belajar aktif. Dari data-data yang telah diperoleh dapat duraikan sebagai berikut:

1. Selama proses belajar mengajar guru telah melaksanakan semua pembelajaran dengan baik. Meskipun ada beberapa aspek yang belum sempurna, tetapi persentase pelaksanaannya untuk masing-masing aspek cukup besar.

2. Berdasarkan data hasil pengamatan diketahui bahwa siswa aktif selama proses belajar berlangsung.

3. Kekurangan pada siklus-siklus sebelumnya sudah mengalami perbaikan dan peningkatan sehingga menjadi lebih baik.

4. Hasil belajar siswa pada siklus III mencapai ketuntasan.

\section{Revisi Pelaksanaan}

Pada siklus III guru telah menerapkan belajar aktif dengan baik dan dilihat dari aktivitas siswa serta hasil belajar siswa pelaksanaan proses belajar mengajar sudah berjalan dengan baik. Maka tidak diperlukan revisi terlalu banyak, tetapi yang perlu diperhatikan untuk tindakah selanjutnya adalah memaksimalkan dan mepertahankan apa yang telah ada dengan tujuan agar pada pelaksanaan proses belajar mengajar selanjutnya penerapan belajar aktif dengan menggunakan metode permainan ini dapat meningkatkan proses belajar mengajar sehingga tujuan pembelajaran dapat tercapai.

\section{Pembahasan}

\section{Ketuntasan Hasil belajar Siswa}

Melalui hasil peneilitian ini menunjukkan bahwa cara belajar aktif Metode Discovery Learning pada materi memiliki dampak positif dalam meningkatkan prestasi belajar siswa. Hal ini dapat dilihat dari semakin mantapnya pemahaman siswa terhadap materi yang disampaikan guru (ketuntasan belajar meningkat dari sklus I, II, dan III) yaitu masing-masing 60\%, 73\%, dan 90\%. Pada siklus III ketuntasan belajar siswa secara klasikal telah tercapai.

\section{Kemampuan Guru dalam Mengelola Pembelajaran}

Berdasarkan analisis data, diperoleh aktivitas siswa dalam proses belajar aktif Metode Discovery Learning dalam setiap siklus mengalami peningkatan. Hal ini berdampak positif terhadap prestasi belajar siswa yaitu dapat ditunjukkan dengan meningkatnya nilai rata-rata siswa pada setiap siklus yang terus mengalami peningkatan.

\section{Aktivitas Guru dan Siswa Dalam Pembelajaran}

Berdasarkan analisis data, diperoleh aktivitas siswa dalam proses pembelajaran Fisika dengan metode belajar aktif Metode Discovery Learning yang paling dominan adalah bekerja dengan menggunakan alat/media, mendengarkan/memperhatikan penjelasan guru, serta diskusi dan kerja sama antar siswa, juga antara siswa dengan guru. Jadi dapat dikatakan bahwa aktivitas siswa dapat 
dikategorikan aktif. Sedangkan untuk aktivitas guru selama pembelajaran telah melaksanakan langkah-langkah belajar aktif dengan baik. Hal ini terlihat dari aktivitas guru yang muncul di antaranya aktivitas membimbing dan mengamati perkembangan siswa dalam mengerjakan kegiatan pembelajaran, menjelaskan/melatih menggunakan alat, memberi umpan balik/evaluasi/tanya jawab dimana prosentase untuk aktivitas di atas cukup besar.

\section{KESIMPULAN}

Berdasarkan hasil kegiatan pembelajaran Fisika materi Listrik Arus Searah yang telah dilakukan selama tiga siklus, dan berdasarkan seluruh pembahasan serta analisis yang telah dilakukan dapat disimpulkan sebagai berikut:

- Pembelajaran Fisika materi Listrik Arus Searah dengan cara belajar aktif Metode Discovery Learning memiliki dampak positif dalam meningkatkan prestasi belajar siswa yang ditandai dengan peningkatan ketuntasan belajar siswa dalam setiap siklus, yaitu siklus I (60\%), siklus II (73\%), siklus III (90\%).

- Penerapan cara belajar aktif Metode Discovery Learning pada mata pelajaran Fisika ini mempunyai pengaruh positif, yaitu dapat meningkatkan motivasi belajar siswa yang ditunjukan dengan rata-rata jawaban siswa yang menyatakan bahwa siswa tertarik dan berminat dengan model belajar aktif sehingga mereka menjadi termotivasi untuk belajar.

- Penerapan cara belajar aktif Metode Discovery Learning pada mata pelajaran Fisika ini bisa meningkatkan penguasaan mata pelajaran Fisika materi Listrik Arus Searah serta pemahaman makna yang terkandung di dalamnya.

\section{UCAPAN TERIMA KASIH}

Terimakasih diucapkan kepada Kepala SMAN 2 Siak Hulu yang sudah memberikan izin dalam melaksanakan penelitian ini. Kepada peserta didik yang sudah berpartisipasi dalam melaksanakan penelitian ini. Kepada pihak Dinas Pendidikan yang sudah memberikan izin dalam dan mendukung dalam melaksanakan penelitian ini.

\section{REFERENSI}

Ali Mudlofir. 2011 Aplikasi Pengembangan Kurikulum Tingkat Satuan Pendidikan (KTSP) dan bahan ajar dalam Pendidikan Agama Islam. Jakarta: Rajawali Pers.

M. Hosnan. 2014. Pendekatan Saintifik dan Kontekstual dalam Pembelajaran Abad 21, cet-2. Bogor: Ghalia Indonesia.

Hanafiah. 2009. Cucu Suhana, Konsep Strategi pembelajaran. Bandung: Refika Aditama.

Ratna Wilis Dahar. 2011. Teori-teori Belajar dan Pembelajaran. Jakarta: Erlangga.

Abdul Majid. 2015. Strategi Pembelajaran, Cet-4. Bandung: PT. Remaja Rosdakarya. 
Penerapan Metode Discovery Learning untuk Meningkatkan Prestasi Belajar Fisika Materi Listrik Arus Searah Pada Siswa Kelas XII MIPA 3 Tahun Pelajaran 2019/2020, Nelda Roza

Suyadi. 2013. Strategi Pembelajaran Pendidikan Karakter. Bandung: Remaja Rosdakarya.

Usep Nuh. 2016. "keterampilan proses sains (online)", dalam http://fisikasma online.blogspot.co.id/2010/03/keterampilan-proses-sains.html, diakses 07 Januari 2016.

Nuryani R. 2005 Strategi Belajar Mengajar Biologi, Cet I. Malang: Universitas Negeri Malang.

Purwanto. 2013. Evaluasi Hasil Belajar. Yogyakarta: Pustaka Pelajar.

Agus Suprijono. 2010. Cooperative Learning Teori \& Aplikasi PAIKEM. Yogyakarta:Pustaka Pelajar. Mulyana Abdurrahman. 2003. Pendidikan Bagi Anak Berkesulitan Belajar. Jakarta: PT.Rineka Cipta. Jamil Suprihatiningrum, Strategi pembelajaran, Purwanto, Evaluasi Hasil Belajar

Nana Sudjana. 2006. Penilaian Hasil Proses Belajar Mengajar. Bandung: PT. Remaja Rosdakarya. 